\title{
Do Occupational Hazards Affect Revenue Earnings of Cassava Processors in Rivers State, Nigeria?
}

\author{
Mercy Ebere Ndubuzee-Ogaraku \\ Department of Agricultural Economics and Extension, Faculty of Agriculture, \\ University of Port Harcourt,PMB 5323 Choba, Port Harcourt,Nigeria. \\ Obinna Darlington Ezeala \\ Department of Agricultural Economics and Extension, Faculty of Agriculture, \\ University of Port Harcourt,PMB 5323 Choba, Port Harcourt,Nigeria.

\section{Zelda Anne Omasanuwa} \\ Department of Agricultural Economics and Extension, Faculty of Agriculture, \\ University of Port Harcourt,PMB 5323 Choba, Port Harcourt,Nigeria.
}

\begin{abstract}
Farming and food processing have been described as one of the most hazardous activities especially in developing countries. The associated hazards have the potential to affect revenue earned by the workers in the agriculture sector. The study was aimed at investigating whether occupational hazards affect revenue earned by cassava processors in Rivers State, Nigeria. Specifically processing activities, occupational hazards and safety measures adopted by the processors were identified. Effects of occupational hazards on revenue earnings of the cassava processors were determined. 25 respondents were randomly selected from four communities in Obio/Akpor and Etche Local Government Areas making a total of 100 respondents. Data were collected with the use of questionnaire administered to the 100 respondents. Results of the study showed that women dominated cassava processing enterprise with the mean age of 43 years. Majority (37.4\%) processed cassava into garri while 32 percent processed cassava into garri and fufu products. Inhalation of smoke ranked highest among the occupational hazard identified. Regression analysis result showed that cost of cassava, quantity of cassava tuber and quantity of fufu had positive influence on revenue earned by the processors at $1 \%$ significant level each. However, the quantity of garri produced showed negative relationship with the revenue earned by the processors at $1 \%$ significant level. Occupational hazard did not show significant effect on amount of revenue earned by cassava processors. It is recommended that management should reenforce the use of personal protective equipment by all workers to reduce occupational risks and hazards in cassava processing firms.
\end{abstract}

Keywords: Occupational hazards, cassava, processors, revenue 
Ndubuzee-Ogaraku, M. E., Ezeala, O. D., \& Omasanuwa, Z. A. (2020). Do Occupational Hazards Affect Revenue Earnings of Cassava Processors in Rivers State, Nigeria? Advances in Social Sciences Research Journal, 7(4) 34-46.

\section{INTRODUCTION}

Cassava (Manihot esculenta) and its by-products are staple food for over 600 million people in large parts of sub-Saharan Africa, South America and Asia. More than half of the world's cassava is produced in Africa, where it is a cheap and major source of calories for over $40 \%$ of the population [1]. Cassava has become economically important in several tropical countries. The carbohydrate content of its enlarged root is consumed in diversified forms in most African countries, including Nigeria [2]. The crop can be planted any time of the year and harvesting can also be done all year round. [3] reported that processed food products from cassava include garri (fermented and roasted granules), fufu (fermented and steamed cooked), pupuru (fermented smoked dried balls and also gelatinized), lafun (fermented, sun dried flour and then gelatinized). Arguably, the processing of cassava into various products comes with a lot of environmental as well as occupational health hazards to the environment, consumers and especially the processors [4]. It is important to state that safety of the processors should be considered in crop processing [2]. Cassava processing entails numerous steps which include harvesting, peeling, grating, dewatering, fermentation, roasting or drying and finally packaging for sales [5]. Reportedly, the most widely adopted method (traditional method) of cassava processing has led to various pathological issues ranging from general body aches, pains and fatigue, and high body temperature due to exposure to smoke in the roasting environment [3]. Thus, processing of cassava has its occupational health hazards and must be given high consideration as cassava products is inseparable from man and animals especially in the developing countries where it is the cheapest staple food used to combat hunger [6]. According to [7], a healthy workforce is one of the most important economic assets to a nation. An unhealthy workforce is therefore an economic loss to a nation which in turn affects the productivity and in this case food security of the nation. [8] defined a hazard as any source of potential damage, harm or adverse health effect on something or someone. Basically, a hazard is something that can cause harm or adverse effects such as to individuals as health effects, to the environment or to organizations as property or equipment damage. The study by [9] reported various occupational hazards in cassava processing to include; physical/environmental hazards such as excessive noise from machines that can cause permanent noise-induced hearing loss or deafness; excessive cold that could lead to hypothermia, frostbite and chilblains and excessive heat which could generate heat cramps, heat exhaustion, heat stroke and heat dermatomes [9]. Furthermore, [10], opined that occupational hazard comprises of cuts or injury sustained from farm tools, malaria due to mosquito bite, and general body pain which reduces productive activities. [11] reported that vibration from machines could lead to hand-arm vibration syndrome (HAVS), which are more prevalent among farm workers. Farmers are also vulnerable to epidemic fevers, cholera, diarrhea and dysentery [8]. Empirically, studies in time past have identified common occupational hazards emanating from agricultural production. [3], listed factors that could lead to hazards in cassava processing as; lack of water, lack of effective channel for cassava effluent, lack of labour and unstable price of cassava products. [12] opined that exposure to occupational health hazard could damage many lives and livelihoods which would impede economic growth. Poor and unsafe work conditions are both a cause and consequence of poverty in any profession [12].

A study conducted by [13] and (1996) [14] revealed that farmers experienced income loss due to existing occupational health hazard. Similarly, [15] noted that women processors were exposed to chemical, physical and psychosocial hazards during cassava processing activities. It was further noted that lower back pain and other musculoskeletal disorder were the most recurring health issues faced by the processors. On this background, it is imperative to assess various occupational 
hazard associated with cassava processing activities. As such, the study was designed to analyze the occupational hazards among cassava processors in Rivers State, Nigeria. Specifically, the socioeconomic characteristics of the cassava processors in Rivers State, Nigeria were described; various processing activities in cassava processing were identified; occupational hazards associated with cassava processing were also identified. In addition, the safety measures adopted by the cassava processors were identified and the effects of the identified occupational hazards on revenue earnings of the cassava processors were determined.

\section{Study Area}

\section{METHODOLOGY}

This study was conducted in Rivers State in the South-South zone of Nigeria. Its capital and largest city, Port Harcourt, lies along the Bonny River (an eastern distributary of the Niger River) 41 miles (66 km) upstream from the Gulf of Guinea. Rivers State lies between latitude $30^{\circ} 4^{\prime \prime} \mathrm{N}$ and $45^{\circ} 5^{\prime \prime} \mathrm{N}$ approximately longitude $30^{\circ} 6^{\prime \prime} \mathrm{E}$ and $30^{\circ} 7^{\prime \prime} \mathrm{E}$ of the Greenwich Meridian with total area of 11,077 $\mathrm{km}^{2}$ which is bounded on the South by the Atlantic Ocean, to the North by Imo, Abia and Anambra States, to the East by Akwa Ibom State and to the West by Bayelsa and Delta states. According to the population projection of the National Bureau of Statistics [16], Rivers state has a population of $7,303,924$, making it the sixth-most populous state in the country. The state is divided into 3 agricultural zones which comprises of 23 Local Government Areas (LGAs) of Rivers State. This study was carried out in Obio-Akpor and Etche L.G.As in Rivers State. Obio/Akpor LGA has a population of 464,789 people [17]. Etche LGA has thirty-eight (38) communities and a total population of 249,939 persons [18] .

\section{Sampling Technique}

A multi-stage sampling procedure was used to select the respondents for this study. The first stage involved a purposive selection of the two Local Government Areas namely, Obio-Akpor and Etche LGAs. This is because the two local governments are well known for cassava production. The second stage involved a random selection of four (4) communities namely; Rumuolumeni and Rukpokwu from Obio-Akpor L.G.A, Chokocho and Okehi from Etche L.G.A. With the assistance of the Agricultural Extension Agents in the Local Government Areas, the lists of registered cassava processors were compiled and this formed the sampling frame from which 25 cassava processors were randomly selected from each of the four (4) communities to make a total sample size of 100 cassava processors. However, ninety-nine (99) questionnaire were retrieved and used for analysis. Structured questionnaire and interview schedule were used in the primary data collection. The study also relied on secondary data from textbooks, journals, books, newspaper article and reliable internet web pages.

\section{Model Specifications}

Ordinary Least Squares (OLS) regression analysis was used to examine the effects of occupational hazards on the revenue earnings of the cassava processing enterprise, testing for the significant relationship between the occupational hazards faced by cassava processors and the revenue earnings of the cassava processing enterprise.

\section{Regression model specification:}

Implicit form; $Y=f(X)$

Explicit form; $Y=f\left(X_{1}, X_{2}, X_{3}, X_{4}, X_{5}, X_{6}, X_{7}, X_{8}, X_{9}, X_{10}, e\right)$ 
Where,

- $\mathrm{Y}=$ Revenue earned by processors ( $\mathrm{H}$ )

- $\mathrm{X}_{1}=$ Age of processor (years)

- $\mathrm{X}_{2}=$ Educational level (years)

- $\mathrm{X}_{3}=$ Processing experience (years)

- $\mathrm{X}_{4}=$ Cost of cassava tuber ( $\left.\mathrm{N}\right)$

- $\mathrm{X}_{5}=$ Quantity of cassava tuber $(\mathrm{kg})$

- $\mathrm{X}_{6}=$ Quantity of fufu (kg)

- $\mathrm{X}_{7}=$ Quantity of garri $(\mathrm{kg})$

- $\mathrm{X}_{8}=$ Occupational hazard 1 (Smoke inhalation)

- $\mathrm{X}_{9}=$ Occupational hazard 2 (fatigue)

- $\mathrm{X}_{10}=$ Occupational hazard 3(joint pain)

- $\mathrm{e}=$ error term

The relationship between the dependent and each of the independent variables will be examined using the four functional forms: Linear regression, semi-log form and Double-log form.

\section{Regression model functional forms}

\section{Linear:}

$Y=\beta_{0}+\beta_{1} X_{1}+\beta_{2} X_{2}+\beta_{3} X_{3}+\beta_{4} X_{4}+\beta{ }_{5} X_{5}+\beta_{6} X_{6}+\beta_{7} X_{7}+\beta_{8} X_{8}+\beta_{9} X_{9}+\beta{ }_{10} X_{10}+e$

\section{Semi-Log:}

$\log Y=\beta_{0}+\beta_{1} X_{1}+\beta_{2} X_{2}+\beta_{3} X_{3}+\beta_{4} X_{4}+\beta_{5} X_{5}+\beta_{6} X_{6}+\beta_{7} X_{7}+\beta_{8} X_{8}+\beta_{9} X_{9}+\beta_{10} X_{10}+e$

\section{Double Log:}

$\log Y=\beta_{0}+\beta_{1} \log X_{1}+\beta_{2} \log X_{2}+\beta_{3} \log X_{3}+\beta_{4} \log X_{4}+\beta_{5} \log X_{5}+\beta_{6} \log X_{6}+\beta_{7} \log X_{7}+\beta_{8} \log X_{8}+\beta_{9} 10 g X_{9}$

$+\beta_{10} \log X_{10}+e$

$\beta_{0}=$ intercept

$\mathrm{B}_{1}, \beta_{2} \ldots \beta_{10}=$ estimated coefficients. 


\section{RESULTS AND DISCUSSION}

Socio-economic characteristics of cassava processors in the study area, Nigeria.

The results of the socio-economic characteristics of the cassava processors in the study area are presented in Table 1.

\begin{tabular}{|c|c|c|c|}
\hline Variables & Frequency $(n=99)$ & Percentage & Mean \\
\hline Gender & 37 & 37.4 & \\
\hline $\begin{array}{l}\text { Male } \\
\text { Female } \\
\text { Age in years }\end{array}$ & 62 & 62.6 & \\
\hline $1-30$ & 12 & 12.1 & 43 \\
\hline $31-40$ & 36 & 36.4 & \\
\hline $41-50$ & 21 & 21.2 & \\
\hline $51-60$ & 21 & 21.2 & \\
\hline 60 years $\&$ above & 9 & 9.1 & \\
\hline \multicolumn{4}{|l|}{ Marital status: } \\
\hline Single & 16 & 16.2 & \\
\hline Married & 67 & 67.7 & \\
\hline Divorced or separated & 2 & 2.0 & \\
\hline Widowed & 14 & 14.1 & \\
\hline \multicolumn{4}{|l|}{ Educational level: } \\
\hline Non-formal education & 10 & 10.1 & 13 \\
\hline Primary education & 13 & 13.1 & \\
\hline Secondary education & 36 & 36.4 & \\
\hline Tertiary education & 40 & 40.4 & \\
\hline \multicolumn{4}{|l|}{$\begin{array}{l}\text { Processing } \\
\text { experience (years): }\end{array}$} \\
\hline $1-5$ & 29 & 29.3 & 10 \\
\hline $6-10$ & 37 & 37.4 & \\
\hline $11-20$ & 16 & 16.2 & \\
\hline Above 20 & 17 & 17.2 & \\
\hline \multicolumn{4}{|l|}{$\begin{array}{l}\text { Cooperative } \\
\text { membership }\end{array}$} \\
\hline Non-member & 83 & 83.8 & \\
\hline Member & 16 & 16.2 & \\
\hline \multicolumn{4}{|l|}{ Average Income $(\mathbb{N})$ : } \\
\hline Less than 50,000 & 72 & 72.7 & 89412 \\
\hline $51,000-100,000$ & 8 & 8.1 & \\
\hline $101,000-200,000$ & 13 & 13.1 & \\
\hline $201,000-300,000$ & 2 & 2.0 & \\
\hline 300,000 and above & 4 & 4.0 & \\
\hline
\end{tabular}

Source: Field survey, 2019

Results in Table 1 showed that cassava processing is dominated by the female sex. This finding agrees with [19] which found that about 78.6 percent of cassava processors are female, as processing of agricultural products is generally seen as a female job. This could be explained by the role played by women in farming families as the principal producers in its subsistence agricultural production especially in developing countries. They are also the prime producers of staple food in most Africa countries. The mean age of the respondents was 43 years. This implies that on the average, the respondents are in their active years and are expected to be actively involved in farming and processing activities just as reported by [20] in a study that farmers in the age range 
Ndubuzee-Ogaraku, M. E., Ezeala, O. D., \& Omasanuwa, Z. A. (2020). Do Occupational Hazards Affect Revenue Earnings of Cassava Processors in Rivers State, Nigeria? Advances in Social Sciences Research Journal, 7(4) 34-46.

participated actively in production and processing of agricultural products. The study also agree with the findings of Korir (2011) [21] which showed that married individuals participated actively in agricultural production. Education is an important means of knowledge acquisition needed in decision making. The result showed that 89.9 percent of the respondents had formal education and only 10.1 percent of them had no formal education. The high level of literacy among processors would definitely influence the rates of adoption of modern techniques in cassava processing. [22] made similar observation while accessing occupational hazards, health problems and peakexpiratory flow rates of local garri processors in a rural community in South-South, Nigeria. It was showed that 33.4 percent of the respondents had more than 10 years' experience. This is an indication that an average processor had ample knowledge of the occupational hazards inherent in cassava processing. The result indicated that majority (83.8\%) respondents of the respondents are non-members of associations and this may have hindered them from experiencing benefits associated with group action such as opportunity of group bargain, capital mobilization and training or sharing of relevant information. Only (16.2\%) of respondents belong to group association like; Cassava Farmers Association, Cassava Growers and Processors Association, Okehi Cassava Association, Etche Cassava Farmers Association. Result in Table 1 also indicated that majority $(72.7 \%)$ of the respondents earned below $\$ 50,000$, per month as they mainly engaged in cassava processing to supplement the income gotten from other menial jobs. Only $(4.0 \%)$ of the sampled population earned earning $\$ 300,000$ and above per month. This shows that a few respondents were engaged in large-scale commercial cassava processing operation in the study area.

\section{Cassava Processing Activities}

Table 2 Respondents' distribution based on cassava processing activities in the study area.

\begin{tabular}{lll}
\hline Variables & Frequency(n=99) & Percentage (\%) \\
\hline Cassava processing activities & & \\
Garri processing & 37 & 37.4 \\
Fufu Processing & 30 & 30.3 \\
Garri and fufu processing & 32 & 32.3 \\
Total & $\mathbf{9 9}$ & $\mathbf{1 0 0 . 0}$ \\
\hline
\end{tabular}

Source: Field survey, 2019.

The results in Table 2 presents the processing activities carried out by processors in the study area. It shows that majority of the cassava processors (37.4\%) processed cassava tubers into garri than other value products. Processing of cassava into garri product would likely due to the fact that garri is most consumed cassava product in the study area. This however, disagrees with the findings of [23] who reported that most processors engage in garri and fufu production. A relative high percentage of the respondents (32.3\%) also engaged in garri and fufu production because consumption of the food types is a prominent local diet in the study area. 
Occupational Hazards associated with cassava processing in the study area.

\begin{tabular}{|c|c|c|c|c|c|c|c|}
\hline $\begin{array}{c}\text { Occupational hazard } \\
\mathrm{N}=99 \\
\end{array}$ & Never & Rarely & Regular & $\begin{array}{l}\text { Very } \\
\text { often }\end{array}$ & Mean & Rank & Remark \\
\hline $\begin{array}{l}\text { Inhalation of smoke while } \\
\text { frying garri }\end{array}$ & $1(1.0 \%)$ & $10(10.1 \%)$ & $42(42.4 \%)$ & $46(46.5 \%)$ & 2.3434 & $1^{\text {st }}$ & High \\
\hline $\begin{array}{l}\text { Fatigue as a result of } \\
\text { strenuous nature of } \\
\text { processing }\end{array}$ & $4(4.0 \%)$ & $5(5.1 \%)$ & $46(46.5 \%)$ & $44(44.4 \%)$ & 2.3131 & $2^{\text {nd }}$ & High \\
\hline $\begin{array}{l}\text { Joint pain while } \\
\text { stirring/pounding fufu }\end{array}$ & $5(5.1 \%)$ & $13(13.1 \%)$ & $46(46.5 \%)$ & $35(35.4 \%)$ & 2.1212 & $3^{\text {rd }}$ & High \\
\hline $\begin{array}{l}\text { Eye irritation due to } \\
\text { smoking during garri } \\
\text { processing }\end{array}$ & $3(3.0 \%)$ & $13(13.1 \%)$ & $53(53.5 \%)$ & $30(30.3 \%)$ & 2.1111 & $4^{\text {th }}$ & High \\
\hline $\begin{array}{l}\text { Body exposure to excessive } \\
\text { heat while frying or } \\
\text { cooking cassava }\end{array}$ & $9(9.1 \%)$ & $9(9.1 \%)$ & $57(57.61 \%)$ & $24(24.2 \%)$ & 1.9697 & $5^{\text {th }}$ & High \\
\hline Cuts while peeling cassava & $3(3.0 \%)$ & $33(33.3)$ & $54(54.5 \%)$ & $9(9.1 \%)$ & 1.6970 & $6^{\text {th }}$ & High \\
\hline $\begin{array}{l}\text { Insect bite while } \\
\text { processing cassava }\end{array}$ & $5(5.1 \%)$ & $34(34.3 \%)$ & $49(49.5 \%)$ & $11(11.1 \%)$ & 1.6667 & $7^{\text {th }}$ & High \\
\hline $\begin{array}{l}\text { Burns and scalds from } \\
\text { cooking/boiling fufu }\end{array}$ & $8(8.1 \%)$ & $34(34.3 \%)$ & $44(44.4 \%)$ & $13(13.1 \%)$ & 1.6263 & $8^{\text {th }}$ & High \\
\hline $\begin{array}{l}\text { Skin irritation due to } \\
\text { excessive heat while frying }\end{array}$ & $6(6.1 \%)$ & $36(36.4 \%)$ & $47(47.5 \%)$ & $10(10.1 \%)$ & 1.6162 & $9^{\text {th }}$ & High \\
\hline $\begin{array}{l}\text { Headache due to strenuous } \\
\text { work while processing }\end{array}$ & $19(19.2 \%)$ & $44(44.4 \%)$ & $40(40.4 \%)$ & $12(12.1 \%)$ & 1.6162 & $10^{\text {th }}$ & \\
\hline Hearing loss & $19(19.2 \%)$ & $38(38.4 \%)$ & $33(33.3 \%)$ & $9(9.1 \%)$ & 1.5152 & $11^{\text {th }}$ & High \\
\hline $\begin{array}{l}\text { Malaria and typhoid due to } \\
\text { insect infestation while } \\
\text { processing cassava }\end{array}$ & $11(11.1)$ & $48(48.5 \%)$ & $24(24.2 \%)$ & $16(16.2 \%)$ & 1.4545 & $12^{\text {th }}$ & High \\
\hline $\begin{array}{l}\text { Catarrh while sieving } \\
\text { cassava flour }\end{array}$ & $15(15.2 \%)$ & $60(60.6 \%)$ & $20(20.2 \%)$ & $4(4.0 \%)$ & 1.1313 & $13^{\text {th }}$ & Low \\
\hline $\begin{array}{l}\text { Sustained injury while } \\
\text { transporting cassava to } \\
\text { processing unit }\end{array}$ & $33(33.3 \%)$ & $58(58.6 \%)$ & $6(6.1 \%)$ & $2(2.0 \%)$ & 0.7677 & $14^{\text {th }}$ & Low \\
\hline $\begin{array}{l}\text { Exposure to the hazardous } \\
\text { cyanide content during } \\
\text { dewatering of cassava }\end{array}$ & $56(56.6 \%)$ & $23(23.2 \%)$ & $17(17.2 \%)$ & $3(3.0 \%)$ & 0.6667 & $15^{\text {th }}$ & Low \\
\hline $\begin{array}{l}\text { Damage to the lungs due to } \\
\text { inhalation of } \\
\text { smoke while frying garri }\end{array}$ & $49(49.5 \%)$ & $39(39.4 \%)$ & $11(11.1 \%)$ & $0(0.00 \%)$ & 0.6161 & $16^{\text {th }}$ & Low \\
\hline $\begin{array}{l}\text { Cyanide food poisoning due } \\
\text { to improper dewatering }\end{array}$ & $66(66.7 \%)$ & $21(21.2 \%)$ & $9(9.1 \%)$ & $3(3.0 \%)$ & 0.4848 & $17^{\text {th }}$ & Low \\
\hline $\begin{array}{l}\text { Death due to snake bite } \\
\text { while processing cassava }\end{array}$ & $90(90.7 \%)$ & $8(8.1 \%)$ & $1(1.0 \%)$ & $0(0.00 \%)$ & 0.1010 & $18^{\text {th }}$ & Low \\
\hline
\end{tabular}

Source: Field Survey, 2019; 1-18 implies, highest to lowest rank; mean ( $\geq 1.5)$ : high hazard, mean $(<1.5)$; low hazard. 
Ndubuzee-Ogaraku, M. E., Ezeala, O. D., \& Omasanuwa, Z. A. (2020). Do Occupational Hazards Affect Revenue Earnings of Cassava Processors in Rivers State, Nigeria? Advances in Social Sciences Research Journal, 7(4) 34-46.

The Results in Table 3 showed that a majority of 46.5 percent of the respondents perceived and experienced inhalation of smoke while frying garri as the most experienced and hazardous task in cassava processing activities. This finding agrees with [24] who found that an overwhelming majority of $97.8 \%$ perceived the inhalation of smoke while frying garri to be hazardous to the processors' health. This occupational hazard ranked $1^{\text {st }}$ with a mean of 2.3434. Fatigue as a result of the strenuous nature of processing and joint pain while stirring/pounding fufu ranked $2^{\text {nd }}$ and $3^{\text {rd }}$ respectively. Furthermore, 90.7 percent of the processors indicated they never experienced snake bite while processing cassava. Only 1.0\% experienced this hazard and this is on a 'less often' basis. This hazard ranked least with a mean of 0.10 .

Safety measures adopted by cassava processors.

Table 4. Distribution of respondents according to the safety measures adopted in the study area

\begin{tabular}{|c|c|c|c|c|c|c|}
\hline Safety measures & Never & Rarely & Regular & Very often & Mean & Rank \\
\hline $\begin{array}{l}\text { Use of footwear to } \\
\text { prevent snake bite }\end{array}$ & $25(25.3 \%)$ & $27(27.3 \%)$ & $32(32.3 \%)$ & $15(15.2 \%)$ & 2.3737 & $1^{\text {st }}$ \\
\hline $\begin{array}{l}\text { Use of sun hats/caps } \\
\text { to prevent excessive } \\
\text { heat }\end{array}$ & $33(33.3 \%)$ & $30(30.3 \%)$ & $23(23.2 \%)$ & $13(13.1 \%)$ & 2.1616 & $2^{\text {nd }}$ \\
\hline $\begin{array}{l}\text { Use of shed/earthen } \\
\text { platform to avoid } \\
\text { excessive heat }\end{array}$ & $32(32.3 \%)$ & $37(37.4 \%)$ & $18(18.2 \%)$ & $12(12.1 \%)$ & 2.1010 & $3^{\text {rd }}$ \\
\hline $\begin{array}{l}\text { Use of hand gloves to } \\
\text { prevent cut while } \\
\text { peeling cassava }\end{array}$ & $40(40.4 \%)$ & $28(28.3 \%)$ & $24(24.2 \%)$ & $7(7.1 \%)$ & 1.9798 & $4^{\text {th }}$ \\
\hline $\begin{array}{l}\text { Medical check-up } \\
\text { every month }\end{array}$ & $35(35.4 \%)$ & $39(39.4 \%)$ & $22(22.2 \%)$ & $3(3.0 \%)$ & 1.9293 & $5^{\text {th }}$ \\
\hline $\begin{array}{l}\text { Use of coverall to } \\
\text { prevent skin irritation }\end{array}$ & $54(54.5 \%)$ & $20(20.2 \%)$ & $17(17.2 \%)$ & $8(8.1 \%)$ & 1.7879 & $6^{\text {th }}$ \\
\hline $\begin{array}{l}\text { Use of nose guard } \\
\text { while sieving dry } \\
\text { cassava paste }\end{array}$ & $58(58.6 \%)$ & $26926.3 \%)$ & $7(7.1 \%)$ & $8(8.1 \%)$ & 1.6465 & $7^{\text {th }}$ \\
\hline $\begin{array}{l}\text { Use of safety glasses } \\
\text { while roasting/frying } \\
\text { garri }\end{array}$ & $66(66.7 \%)$ & $15(15.2 \%)$ & $12(12.1 \%)$ & $6(6.1 \%)$ & 1.5758 & $8^{\text {th }}$ \\
\hline $\begin{array}{l}\text { Use of palm-oil on the } \\
\text { body to scare the } \\
\text { insects away during } \\
\text { harvesting and frying } \\
\text { garri }\end{array}$ & $75(75.8 \%)$ & $21(21.2 \%)$ & $3(3.0 \%)$ & $0(0.00 \%)$ & 1.2727 & $9^{\text {th }}$ \\
\hline
\end{tabular}

Source: Field survey, 2019; 1-9 implies, highest to lowest rank. 
The result in Table 4 shows that only 15.2 percent of the respondents utilized footwear to prevent snakebite which ranked $1^{\text {st }}$ as the safety measure adopted by the processors. This result corroborates with [24] findings that only 3.3\% of the respondents utilized footwear (covering entire foot) while engaging in cassava processing activities. It was found that $13.1 \%$ and $12.1 \%$ of the processors used sun hats/caps and shed / earthen platform often to prevent excessive heat during processing with mean of 2.1616 and 2.1010 which ranked $2^{\text {nd }}$ and $3^{\text {rd }}$ respectively. The use of palm oil on the body to scare insects away during harvesting and frying of garri ranked the least with a weighted mean score of only 1.2727. This is so because cassava processors dislike its use as it is an unpleasant and unhygienic way of scaring insects away during cassava processing activities.

Effects of Occupational hazards on the revenue earnings of the cassava processors in the study area.

Table 5: The OLS Regression model result

\begin{tabular}{|c|c|c|c|c|}
\hline Variables & Linear & Semi-log & Double-log & Exponential \\
\hline Constant & $\begin{array}{c}8890.748 \\
(0.822513)\end{array}$ & $\begin{array}{c}8.981287^{* * *} \\
(15.13523)\end{array}$ & $\begin{array}{c}-0.001524 \\
(-0.000912)\end{array}$ & $\begin{array}{c}-6179995 . * * * \\
(-3.416973)\end{array}$ \\
\hline Age & $\begin{array}{c}-165.7491 \\
(-0.671765)\end{array}$ & $\begin{array}{c}0.010360 \\
(0.764814)\end{array}$ & $\begin{array}{c}0.378553 \\
(1.459345)\end{array}$ & $\begin{array}{l}-214172.4 \\
(0.763065)\end{array}$ \\
\hline Educational level & $\begin{array}{c}-567.5362 \\
(-1.602274)\end{array}$ & $\begin{array}{c}0.015003 \\
(0.771553)\end{array}$ & $\begin{array}{c}0.165039 \\
(1.714011)\end{array}$ & $\begin{array}{c}-41245.13 \\
(-0.395883)\end{array}$ \\
\hline $\begin{array}{l}\text { Processing } \\
\text { experience }\end{array}$ & $\begin{array}{c}367.8576 \\
(1.094789)\end{array}$ & $\begin{array}{c}-0.015808 \\
(-0.856974)\end{array}$ & $\begin{array}{c}-0.119495 \\
(1.180683)\end{array}$ & $\begin{array}{c}48594.03 \\
(0.443744)\end{array}$ \\
\hline Cost of cassava tuber & $\begin{array}{c}1.756657^{* * *} \\
(5.461318)\end{array}$ & $\begin{array}{c}-1.49 \mathrm{E}-05 \\
(-0.846613)\end{array}$ & $\begin{array}{c}0.576123 \\
(1.197848)\end{array}$ & $\begin{array}{c}1667526 \text {.** }^{* *} \\
(3.204244)\end{array}$ \\
\hline Quantity of cassava & $\begin{array}{c}2.223777^{* * *} \\
(7.98844)\end{array}$ & $\begin{array}{c}-6.14 \mathrm{E}-05^{* * *} \\
(-4.019954)\end{array}$ & $\begin{array}{c}-0.019384 \\
(-0.314111)\end{array}$ & $\begin{array}{c}33876.36 \\
(0.507345)\end{array}$ \\
\hline Quantity of fufu & $\begin{array}{c}75.88111^{* * *} \\
(18.70842)\end{array}$ & $\begin{array}{c}0.000862^{* * *} \\
(3.872740)\end{array}$ & $\begin{array}{c}1.084763^{* * *} \\
(17.29610)\end{array}$ & $\begin{array}{c}119355.2 \\
(1.758820)\end{array}$ \\
\hline Quantity of garri & $\begin{array}{c}-273.9358^{* * *} \\
(-9.007634)\end{array}$ & $\begin{array}{c}0.007161^{* * * *} \\
(4.289042)\end{array}$ & $\begin{array}{c}-0.548430 \\
(-1.100078)\end{array}$ & $\begin{array}{c}-1672487 . * * * \\
(3.100501)\end{array}$ \\
\hline Inhalation of smoke & $\begin{array}{c}309.1564 \\
(0.586234)\end{array}$ & $\begin{array}{c}0.004105 \\
(0.141792)\end{array}$ & $\begin{array}{c}0.066442 \\
(1.653656)\end{array}$ & $\begin{array}{c}36946.07 \\
(0.849845)\end{array}$ \\
\hline Fatigue & $\begin{array}{l}-35.63013 \\
(0.070800)\end{array}$ & $\begin{array}{c}-0.014245 \\
(-0.515624)\end{array}$ & $\begin{array}{c}-0.059326 \\
(-1.054815)\end{array}$ & $\begin{array}{c}64342.41 \\
(1.057299)\end{array}$ \\
\hline Joint pain & $\begin{array}{c}-330.2278 \\
(-0.676849)\end{array}$ & $\begin{array}{c}6.86 \mathrm{E}-05 \\
(0.002560)\end{array}$ & $\begin{array}{l}0.095019^{* *} \\
(2.111768)\end{array}$ & $\begin{array}{c}-37837.21 \\
(-0.777178)\end{array}$ \\
\hline R-squared & 0.999572 & 0.909911 & 0.993358 & 0.894479 \\
\hline Adjusted R-squared & 0.999334 & 0.859862 & 0.987824 & 0.806545 \\
\hline F-value & 4201.968 & 18.18031 & 179.4798 & 10.17218 \\
\hline
\end{tabular}

Source: Field survey, 2019. Note: ${ }^{* *}$ and ${ }^{* * *}$ denote significance at $5 \%$ and $1 \%$ respectively. values in parenthesis are t-values 
Ndubuzee-Ogaraku, M. E., Ezeala, O. D., \& Omasanuwa, Z. A. (2020). Do Occupational Hazards Affect Revenue Earnings of Cassava Processors in Rivers State, Nigeria? Advances in Social Sciences Research Journal, 7(4) 34-46.

The estimates of the ordinary least square regression analysis which determined the effects of the occupational hazards on the revenue earnings of the cassava processors in the study area is presented in Table 5. Four functional regression model forms were used; linear, semi-log, double$\log$ and exponential functional form. Linear functional form was selected as the lead equation and used for interpretation and discussion. This choice was based on the value of the $\mathrm{R}^{2}$ (coefficient of determination) which considers the model with the highest $\mathrm{R}^{2}$ value to be the best fit. The result shows that the coefficient of determination $\left(R^{2}\right)$ was 0.99 . This shows that $99 \%$ of the variation in revenue earned by the cassava processors was accounted for by the explanatory variables (independent variables) in the model, while the remaining $1 \%$ of the variation was due to other important variables that were not captured in the regression model. The computed $\mathrm{F}$ value (4201.968) is significantly high at $1 \%$ level of significance, denoting that the collective effect of the explanatory variables on the revenue earned by the cassava processors is significant.

The coefficients with positive signs include; cost of cassava tuber, quantity of cassava tuber and the quantity of fufu processed. This implies that an increase in these variables would lead to a corresponding increase in the revenue earned by cassava processors. This is an indication that the variables have a positive effect on revenue. Inversely, quantity of garri produced showed negative sign implying that increasing quantity of garri processing will lead to a decrease in the revenue earned by cassava processors. Cost of cassava tuber was positive at $1 \%$ significant level. This positive relationship implies that increasing the quantity of cassava used in processing would lead to an increase in cost of purchasing cassava tuber which will translate to more quantity of processed cassava products for sales resulting to an increase in the revenue earnings. Also, less amount spent on purchase of cassava tubers would lead to producing lesser quantity of cassava products which could reduce revenue earnings by the cassava processors in the study area. The result also showed that quantity of cassava tubers purchased positively correlates with the revenue earned by the cassava processors at a significant level of $1 \%$.

This means that increasing the quantity of cassava tubers used in processing will definitely increase the revenue earning of the processors. The result also indicated that the coefficient quantity of $f u f u$ showed positive influence on the revenue earned at a $1 \%$ level of significance while quantity of garri produced showed negative influence at $1 \%$ significant level. This implies that increasing quantity of garri would likely reduce revenue earned by the processors. This is not surprising because, garri product market is characterized with relatively large number of sellers and buyers. Since, the market is not regulated, it is possible that at periods of huge supply of garri product into the market, there is price reduction which would reduce level of revenue earning of the processors. The result also indicated that the coefficients of the occupational hazard variables (inhalation of smoke, fatigue as a result of the strenuous nature of processing and joint pain) did not show significant effects on revenue earned. Thus, it could be rightly stated that occupational hazards in cassava processing firms did not influence the earnings of cassava processors in the study area. However, since cassava processing business is usually carried out as a family business, it is possible that when an individual suffers an occupational hazard, other members of the family offer support in carrying out processing activities. This is so, because in Africa, family members are often used as farm labours to support in all farm production and processing activities. 


\section{CONCLUSION}

The study examined occupational hazards among cassava processors in Rivers State, Nigeria. The results showed females dominated cassava processing business. It was shown that majority of the processors processed cassava into garri. As revealed, the major occupational hazards experienced by the cassava processors included inhalation of smoke while frying garri, fatigue due to strenuous processing. The results from the study also showed that major safety measures adopted by the cassava processors in the study area included; the use of footwear to prevent snake bites, sun hats/caps to prevent excessive heat, shed/earthen platform to avoid excessive heat and others. Furthermore, OLS regression indicated that; cost of cassava tuber, quantity of cassava tuber and quantity of fufu produced showed positive relationship with the revenue earned by the cassava while quantity of garri showed negative relationship with revenue earned by cassava processors. However, occupational hazards in cassava processing firms did not influence the earned by cassava processors in the study area.

Therefore, cassava processors are advised to use personal protective equipment to reduce exposure to occupational risks and hazards. This is expected to reduce resources expended on hazard treatment and to increase the average life expectancy of cassava processors. The results call for policies aimed at increasing awareness programmes to sensitize and train farmers especially on the advantages of adopting and utilizing modern cassava processing technologies. There is also need to subsidize the cost of processing machines and encourage young farmers to adopt improved postharvest processing technologies. Government and regulating institutions should enforce compliance to health and safety measures in the industries. Future studies could also be carried out in other parts of the country.

\section{References}

[1] Arthur, M. M., Titus, A., Barbara, Z. M., and Herbert, K. O. (2009). A handbook for the conduct of confined field trials of transgenic cassava in Uganda. Uganda National Council for Science and Technology. 45-56.

[2] Ikechukwu, G. A., and Maduabum, A. (2012). Improved mechanized garri frying technology for sustainable economic development in Nigeria. Proceedings of the International Multi Conference of Engineers and Computer Scientists 2, 12-7.

[3] Oyegbami, A. (2004). Social hazards associated with cassava processing and control management practices. Proceedings of a workshop on promotion of improved management technologies aimed at reducing occupational and environmental hazards associated with cassava processing in Ogun, Ondo and Oyo States.33-37.

[4] Koledoye, G. F., Deji, O. F., Owombo, P. T., and Toromade, O. G. (2012.) Analysis of occupational and environmental hazards associated with cassava processing in Edo State. Nigerian Journal of Agriculture and Food Science 1: 26-32.

[5] Abass, A., Okechukwu, R., James, B., Fannah, S., Sanni, L., Osei-Sarfoh, A., and Lukombo, S. (2012) Producing gari from cassava: An illustrated guide for smallholder cassava processors. International Institute of Tropical Agriculture (IITA): Ibadan, Nigeria.

[6] Omueti, 0. (2004). Traditional cassava processing and improved management practices. Proceedings of a workshop on promotion of improved management technologies aimed at reducing occupational and environmental hazards associated with cassava processing in Ogun, Ondo and Oyo States, 10 (2): 1-5.

[7] Karen, D., Collins, S. R., Doty, M. M., Ho, A., and Holmgren, A. L. (2005). Health and productivity among u.s. workers. Retrieved from https://www.commonwealthfund.org.

[8] Oluwagbemi, B.F. (2007). Basic occupational health and safety: Published by Vertext Media Limited, Ibadan. 
Ndubuzee-Ogaraku, M. E., Ezeala, O. D., \& Omasanuwa, Z. A. (2020). Do Occupational Hazards Affect Revenue Earnings of Cassava Processors in Rivers State, Nigeria? Advances in Social Sciences Research Journal, 7(4) 34-46.

[9] Adedeji, I.A., Olapade-Ogunwole, F., Farayola, C.O., and Adejumo, I.O. (2011). Productivity effects of occupational hazards among poultry farmers and farm workers in Osogbo Local Government Area of Osun State. International Journal of Poultry Science, 10(11): 867-870.

[10] Akangbe, J.A.1., and Komolafe, S.E. (2015). An assessment of knowledge of farming-related hazards and precautionary practices of farmers in kwara state, Nigeria. Journal of Research in forestry, wildlife and environment, $7(2)$.

[11] El-Batami, M.A.(2003). Health of workers in agriculture: World health regional publication, Eastern Mediterranean Series 25.Cairo, Egypt.

[12] Akram, 0 (2014). Occupational health, safety and extreme poverty: A qualitative perspective from Bangladesh. International Journal of Occupational Safety and Health, 4(1): 41 - 50 . DOI: 10.3126/ijosh.v4i1.10654

[13] Oyediran, W., Sodiya, C., Omoare, A., and Ogbonna, C. (2017) Effects of occupational health hazards on artisanal fish production in Ogun State, Nigeria. Fish \& Ocean Opj. 3(2): 1-6.

[14] Ugwu, B.O. (1996). Increasing cassava production in Nigeria and prospects for sustaining the trend. Outlook on Agriculture, 25(3): 179-185.

[15] Adenugba, A.A., and John, P. (2014). Hazardous conditions of women in garri processing industry In Ibadan, South West, Nigeria. Journal of Educational and Social Research, 4(3).

[16] National Bureau of Statistics (NBC, 2011). Annual Abstract of Statistics, Federal Government of Nigeria, Abuja. Available from www.nbs.gov.sc/

[17] National Population Commission (NPC). 2006. Legal notice on publication of 2006 census

[18] Etche Local Government Council. (2010). An unpublished handout on Etche local government area, Okehi, Rivers state, Nigeria.

[19] Ndubueze-Ogaraku, M. E., and Edema, O. I. (2015). Cassava value addition chain analysis in Ughelli North Local Government Area of Delta State, Nigeria. Nigerian Journal of Agriculture, Food and Environment, 11(1): 23-28.

[20] Onasanya AS (2009): Perceived effects of faming-related health problems of farmers' productivity in Yewa north area of Ogun State, Nigeria. The Social Sciences 4: 42-48

[21 Korir, L.K (2011). Risk Management Among Agricultural Households And The Role Of Off-Farm Investments in Uasin Gishu County, Kenya; Unpublished M.Sc, Egerton University, Kenya

[22] Bamidele, J. O., Adeomi, A. A., Adeoye, O. A., and Oladele, K. E. (2014) Occupational Hazards, Health Problems and Peak Expiratory Flow Rates [Pefr] of Local Garri Processors in a Rural Community in South-South, Nigeria. Journal of Neuroinfectious Diseases, 5(2). doi:10.4172/ 2314-7326.1000144.

[23] Ani, D., Ojila, H., and Abu, O. (2019). Profitability of cassava processing: A case study of Otukpo LGA, Benue State, Nigeria. Nigerian Journal of Sustainable Food Production, 6(1), 12-13. doi:10.18052/www.scipress.com/SFP.6.12.

[24] Adabie, D. F. (2015). Occupational health hazards associated with garri production and the possible environmental effects of the resultant effluent. Retrieved from http://ugspace.ug.edu.gh. 